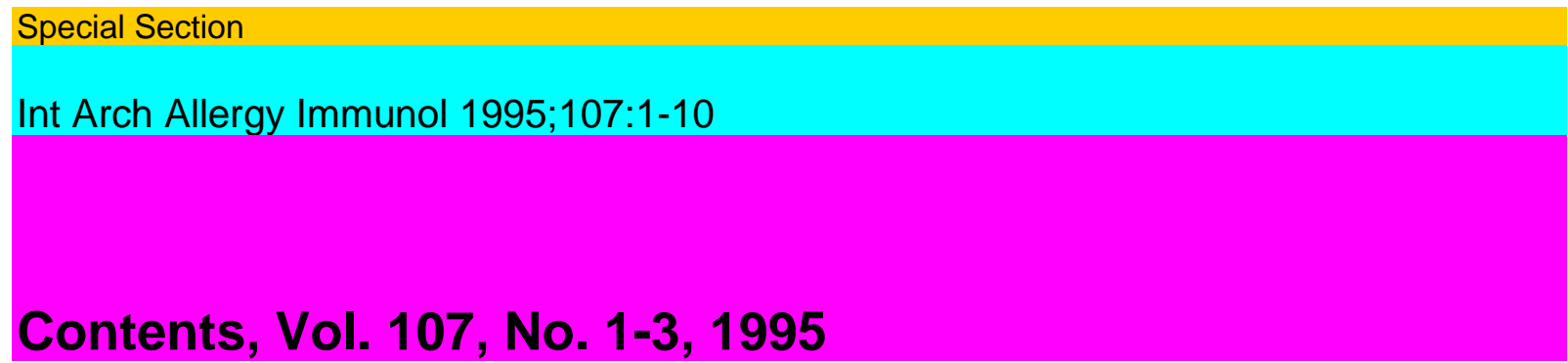

Sheffer, A.L.; Galli, S.J. Introduction 11

The Carl Prausnitz Memorial Lecture

de Week, A.L. What Can We Learn from the Allergic Zoo? 13

The Paul Kallós Memorial Lecture

Austen, K.F. From Slow-Reacting Substance of Anaphylaxis to Leukotriene C4 Synthase 19

Host Factors, Including Genetics

Marsh, D.G.; Neely, J.D.; Breazeale, D.R.; Ghosh, B.; Freidhoff, L.R.; Schou, C; Beaty, T.H.

Genetic Basis of IgE Responsiveness: Relevance to the Atopic Diseases 25

Holgate, ST.; Church, M.K.; Howarth, P.H.; Morton, E.N.; Frew, A.J.; Djukanovic, R. Genetic and Environmental Influences on Airway Inflammation in Asthma 29

Björkstén, B.; Borres, M.P.; Einarsson, R. Interleukin-4, Soluble CD23 and Interferon- $\gamma$ Levels in Serum during the First 18 Months of Life 34

Pathogenesis Regulation of IgE Production

Castigli, E.; Fuleihan, R.; Ramesh, N.; Tsitsikov, E.; Tsytsykova, A.; Geha, R.S. CD40

Ligand/CD40 Deficiency 37

Bonnefoy, J.-Y.; Gauchat, J.-F.; Life, P.; Graber, P.; Aubry, J.-P.; Lecoanet-Henchoz, S.

Regulation of IgE Synthesis by CD23/CD21 Interaction 40

Fuleihan, R.; Ahern, D.; Geha, R.S. Expression of the CD40 Ligand in T Lymphocytes and Induction of IgE Isotype Switching 43

Saxon, A.; Max, E.E.; Diaz-Sanchez, D.; Zhang, K. Alternative RNA of Epsilon Transcripts

Produces mRNAs Encoding Two Membrane and Four Secreted IgE Isoforms 45

Stadler, B.M.; Stämpfli, M.R.; Miescher, S.; Cloning of Human Anti-IgE Autoantibodies and Their Role in the Regulation of IgE 48

Rudolf, M.; Vogel, M. Synthesis

2

Pathogenesis

Cellular Effectors and Regulators of Allergic Reactions

Galli, S.J., Tsai, M.; Wershil, B.K.; Tam, S.-Y.; Costa, J.J. Regulation of Mouse and Human Mast Cell Development, Survival and Function by Stem Cell Factor, the Ligand for c-kit Receptor 51

Kitamura, Y.; Tsujimura, T.; Jippo, T.; Kasugai, T.; Kanakura, Y. Regulation of Development, Survival and Neoplastic Growth of Mast Cells through the c-kit Receptor 54

Chaikin, E.; Hakeem, I.; Razin, E. The Incapability of Interleukin-4 to Induce AP-1 Activity in Murine Mast Cells 57

Metcalfe, D.D. Interaction of Mast Cells with Extracellular Matrix Proteins 60

Saito, H.; Ebisawa, M.; Sakaguchi, N.; Onda, T.; Iikura, Y.; Yanagida, M.; Uzumaki, H.;

Nakahata, T. Characterization of Cord-Blood-Derived Human Mast Cells Cultured in the

Presence of Steel Factor and Interleukin-6 63 
Repetto, B.; Bandara, G.; Wiggan, G.A.; Gilfillan, A.M.; Kochan, J.P. Functional Characterization of the Signal Transduction Events Mediated by FceRI $\alpha$ and $\gamma$ Chimeric Receptors 66

Dinh, T.T.; McClure, G.D.; Kennerly, D.A. Purification and N-Terminal Sequence Analysis of Streptomyces chromofuscus Phospholipase D 69

Marone, G.; Patella, V.; de Crescenzo, G.; Genovese, A.; Adt, M. Human Heart Mast Cells in Anaphylaxis and Cardiovascular Disease 72

Katz, H.R.; Lobell, R.B. Expression and Function of FcyR in Mouse Mast Cells 76

Schroeder, J.T.; Kagey-Sobotka, A.; MacGlashan, D.W.; Lichtenstein, L.M. The Interaction of Cytokines with Human Basophils and Mast Cells 79

Guthmann, M.D.; Tal, M.; Pecht, I. A New Member of the C-Type Lectin Family Is a Modulator of the Mast Cell Secretory Response 82

Dvorak, A.M.; Morgan, E.S.; Monahan-Earley, R.A.; Estrella, P.; Schleimer, R.P.; Weller, P.F.; Tepper, R.I.; Lichtenstein, L.M.; Galli, S.J. Analysis of Mast Cell Activation Using Diamine Oxidase-Gold Enzyme-Affinity Ultrastructural Cytochemistry 87

Bach, M.K.; Brashler, J.R. Evidence that Granulocyte/Macrophage-Colony-Stimulating Factor and Interferon- $\gamma$ Maintain the Viability of Human Peripheral Blood Monocytes in Part by Their Suppression of $\Gamma \mathrm{L}-10$ Production 90

Reddigari, S.; Silverberg, M.; Kaplan, A.P. Assembly of the Human Plasma Kinin-Forming Cascade along the Surface of Vascular Endothelial Cells 93

Pathogenesis

Bonini, S.; Bonini, S.; Lambiase, A.; Magrini, L.; Rumi, C; Del Prete, G.; Schiavone, M.; Rotiroti, G.; Onorati, P.; Rutella, S. Vernal Keratoconjunctivitis: A Model of 5q Cytokine Gene Cluster Disease 95

Canonica, G.W.; Ciprandi, G.; Pesce, G.P.; Buscaglia, S.; Paolieri, F.; Bagnasco, M. ICAM-1 on Epithelial Cells in Allergic Subjects: A Hallmark of Allergic Inflammation 99

Wang, J.H.; Duddle, J.; Devalia, J.L.; Davies, R.J. Nitrogen Dioxide Increases Eosinophil Activation in the Early-Phase Response to Nasal Allergen Provocation 103

Bachert, C; Wagenmann, M.; Hauser, U. Proinflammatory Cytokines: Measurement in Nasal Secretion and Induction of Adhesion Receptor Expression 106

Schierhorn, K.; Brunnée, T.; Schultz, K.-D.; Jahnke, V.; Kunkel, G. Substance-P-Induced Histamine Release from Human Nasal Mucosa in vitro 109

Kips, J.C.; Brusselle, G.G.; Joos, G.F.; Importance of Interleukin-4 and Interleukin-12 in Allergen-Induced Airway Changes 115

Peleman, R.A.; Devos, R.R.; Tavernier, J.H.; $\quad$ jn Mice Pauwels, R.A.

3

Underwood, S.L.; Kemeny, D.M.; Lee, T.H.; $\quad$ Ricin Increases IgE Levels and Airway Inflammation but Not Hyperresponsiveness 119

Raebura, D.; Karlsson, J.-A. m tne Raф

Lamkhioued, B.; Aldebert, D.; Gounni, A.S.; Delaporte, E.; Goldman, M.; Capron, A.; Capron, M. Synthesis of Cytokines by Eosinophils and Their Regulation 122

Simon, H.-U.; Yousefi, S.; Weber, M.; Simon, D.; Hölzer, C; Hartung, K.; Blaser, K. Human Peripheral Blood Eosinophils Express and Release Interleukin-8 124 
Bardin, P.G.; Fraenkel, D.J.; Sanderson, G.; Lampe, F.; Holgate, S.T. Lower Airways

Inflammatory Response during Rhinovirus Colds 127

Wick, G; Kleindienst, R.; Schett, G; Amberger, A.; Xu, Q. Role of Heat Shock Protein 65/60 in the Pathogenesis of Atherosclerosis 130

Development and Function of Effector Cells

Chen, X.-J.; Enerbäck, L. Surface Expression of IgE Receptors, IgE Occupancy and Histamine Releasability of Mast Cells: Influence of Genetic and T Cell Factors 132

Wang, A.V.T.; Scholl, P.R.; Geha, R.S. Association of the High-Affinity Receptor for IgG with the Protein Tyrosine Kinases Hck and Lyn 135

Mekori, Y.A.; Oh, C.K.; Metcalfe, D.D. The Role of c-Kit and Its Ligand, Stem Cell Factor, in Mast Cell Apoptosis 136

Welker, P.; Grabbe, J.; Czarnetzki, B.M. Human Keratinocytes Release Mast Cell Differentiation Factors Other than Stem Cell Factor 139

Li, L.; Macpherson, J.J.; Adelstein, S.; Bunn, C.L.; Atkinson, K.; Phadke, K.; Krilis, SA. Conditioned Medium from a Cell Strain Derived from a Patient with Mastocytosis Induces the Development of Mature Human Mast Cells in vitro from Normal Human Bone Marrow 142 Askenase, P.W.; Geba, G.P.; Levin, J.; Ratzlaff, R.E.; Anderson, G.M.; Ushio, H.; Ptak, W.; Matsuda, H. A Role for Platelet Release of Serotonin in the Initiation of Contact Sensitivity 145 Weber, M; Dahinden, CA. Basophil and Eosinophil Activation by CC Chemokines 148 Warner, JA.; Goldring, K.; Thomas, L.H.; Lavens, S.E. Regulation of Integrin-Dependent Release in Human Lung Mast Cells and Basophils 151

Coleman, J.W.; Buckley, M.G; Taylor, A.M.; Banks, E.M.S.; Williams, C.M.M.; Holliday, M.R.; Thompson, J. Effects of Interleukin-4 or Stem Cell Factor on Mast Cell Mediator Release and Cytokine Gene Expression 154

Bissonnette, E.Y.; Enciso, J.A.; Befus, A.D. Interferon and Antiallergic Drug Regulation of Histamine and Tumor Necrosis Factor- $\alpha$ in Rat Mast Cell Subsets 156

Okayama, Y.; Semper, A.; Holgate, S.T.; Church, M.K. Multiple Cytokine mRNA Expression in Human Mast Cells Stimulated via FceRI 158

Fernandez, J.; Blanca, M.; Moreno, F.; Garcia, J.; Segurado, E.; del Cano, A.; Aguilar, F. Role of Typtase, Eosinophil Cationic Protein and Histamine in Immediate Allergic Reactions to Drugs 160

Pathogenesis and Management

Carlsen, K.-H.; Lødrup Carlson, K.C.; Halvorsen, R. Tidal Flow Volume Loops and Inflammatory Indicators in Small Children 163

Gergen, P.J.; Goldstein, RA. Does Asthma Education Equal Asthma Intervention? 166

Aalberse, R.C.; van Ree, R.; Danneman, A.; Wahn, U. IgE Antibodies to Tetanus Toxoid in Relation to Atopy 169

Moneret-Vautrin, D. A.; Kanny, G; Guéant, J.L.; Prevention by Monovalent Haptens of IgEDependent Leucocyte Histamine Release 172

Widmer, S.; Laxenair, M.C. to Muscle Relaxants

4 Contents

Viale, G; Vercelli, D. Interleukin-13 Regulates the Phenotype and Function of Human Monocytes 176

Neuber, K.; Steinbrücke, K.; Ring, J. Staphylococcal Enterotoxin B Affects in vitro IgE Synthesis, Interferon- $\gamma$, Interleukin-4 and Interleukin-5 Production in Atopic Eczema 179 
Ebner, C; Siemann, U.; Najafian, N.; Scheiner, 0.; Kraft, D. Characterization of Allergen (Bet v 1)-Specifíc T Cell Lines and Clones from Non-Allergic Individuals 183

Noble, A.; Kemeny, D.M. Interleukin-4 and Interferon- $\gamma$ Regulate Differentiation of CD8+ T Cells into Populations with Divergent Cytokine Profiles 186

Iikura, Y.; Iwasaki, A.; Tsubaki, T.; Akasawa, A.; Onda, T.; Katsunuma, T.; Miura, K.; Ebisawa, M; Saito, H.; Koya, N.; Kajiwara, M. Study of Liver Function in Infants with Atopic Dermatitis Using the 13C-Methacetin Breath Test 189

Schmutzler, W.; Bolsmann, K.; Zwadlo-Klarwasser, G. Comparison of Histamine Release from Human Blood Monocytes, Lymphocytes, Adenoidal and Skin Mast Cells 194

Masini, E.; Mugnai, L.; Foschi, M.; Laffi, G.; Gentilini, P.; Mannaioni, P.F. Changes in the

Production of Nitric Oxide and Superoxide by Inflammatory Cells in Liver Cirrhosis 197

Neuroallergology

Undem, B.J.; Riccio, M.M.; Weinreich, D.; Ellis, J.L.; Myers, A.C. Neurophysiology of Mast

Cell-Nerve Interactions in the Airways 199

Goetzl, E.J.; Xia, M.; Ingram, DA.; Kishiyama, J.L.; Kaltreider, H.B.; Byrd, P.K.; Ichikawa, S.;

Sreedharan, S.P. Neuropeptide Signaling of Lymphocytes in Immunological Responses 202

Gleich, G.J.; Jacoby, D.B.; Fryer, A.D. Eosinophil-Associated Inflammation in Bronchial

Asthma: A Connection to the Nervous System 205

Pathogenesis of Asthma and Other Inflammatory Reactions

Kay, A.B.; Ying, S.; Durham, S.R. Phenotype of Cells Positive for Interleukin-4 and Interleukin5 mRNA in Allergic Tissue Reactions 208

Bousquet, J.; Vignola, A.M.; Chanez, P.; Campbell, A.M.; Bonsignore, G.; Michel, F.-B.

Airways Remodelling in Asthma: No Doubt, No More? 211

Laitinen, L.A.; Laitinen, A. Inhaled Corticosteroid Treatment and Extracellular Matrix in the Airways in Asthma 215

Staynov, D.Z.; Cousins, D.J.; Lee, T.H. A Conserved Motif in the Promoters of Several Cytokines Expressed by Human Th2-Type Lymphocytes 217

Mori, A.; Suko, M.; Tsuruoka, N.; Kaminuma, 0.; Ohmura, T.; Nishizaki, Y.; Ito, K.; Okudaira, H. Allergen-Specific Human T Cell Clones Produce Interleukin-5 upon Stimulation with the Thl Cytokine Interleukin-2 220

Tonnel, A.B.; Pestel, J.; Duez, C; Jeannin, P.; Cesbron, J.Y.; Capron, A. Human IgE in Severe Combined Immunodeficiency Mice Reconstituted with Peripheral Blood Mononuclear Cells from Dermatophagoidespteronyssinus-Sensitive Patients 223

Alam, R.; Pazdrak, K.; Stafford, S.; Forsythe, P. The Interleukin-5/Receptor Interaction

Activates Lyn and Jak2 Tyrosine Kinases and Propagates Signals via the Ras-Raf-1-MAP Kinase and the Jak-STAT Pathways in Eosinophils 226

Howarth, P.H.; Redington, A.E.; Springall, D.R.; Martin, U.; Bloom, S.R.; Polak, J.M.; Holgate, S.T. Epithelially Derived Endothelin and Nitric Oxide in Asthma 228

Knop, J.; Enk, A.H. Cellular and Molecular Mechanisms in the Induction Phase of Contact Sensitivity 231

Dvorak, H.F.; Detmar, M.; Claffey, K.P.; $\quad$ Vascular Permeability Factor/Vascular Endothelial Growth Factor: An Important 233

Nagy, J.A.; van de Water, L.; Senger, D.R. Mediator of Angiogenesis in Malignancy and Inflammation

5

Allergens, Immunotherapy and Management 
Koren, H.S.; Bromberg, P.A. Respiratory Responses of Asthmatics to Ozone 236

Denburg, J.A.; Woolley, M.J.; Ellis, R.; Dahlback, M.; O’Byrne, P.M. Allergen-Induced

Changes in Bone Marrow Progenitors and Airway Responsiveness in Dogs 239

Becker, W.-M.; Bufe, A.; Petersen, A.; Schlaak, M. Molecular Characterization of Timothy

Grass Pollen Group V Allergens 242

Reese, G.; Daul, C.B.; Lehrer, S.B. Antigenic Analysis (IgE and Monoclonal Antibodies) of the Major Shrimp Allergen Pen a 1 (Tropomyosin) from Penaeus aztecus 245

Burks, A.W.; Cockrell, G.; Stanley, J.S.; Helm, R.M.; Bannon, G.A. Isolation, Identification, and Characterization of Clones Encoding Antigens Responsible for Peanut Hypersensitivity 248

Panzani, R.C.; Schiavino, D.; Nucera, E.; Pellegrino, S.; Fais, G; Schinco, G; Patriarca, G. Oral Hyposensitization to Nickel Allergy: Preliminary Clinical Results 251

Okudaira, H; Mori, A.; Suko, M.; Etoh, T.; Nakagawa, H.; Ito, K. Enhanced Production and Gene Expression of Interleukin-5 in Patients with Bronchial Asthma: Possible Management of Atopic Diseases by Down-Regulation of Interleukin-5 Gene Transcription 255

Hilger, R.A.; Roller, M.; Rönig, W. Immunosuppressive Agents Enhance the Cytokine-Induced Priming of Inflammatory Cells 259

Triggiani, M.; Oriente, A.; de Crescenzo, G; Rossi, G; Marone, G Biochemical Functions of a Pool of Arachidonic Acid Associated with Triglycerides in Human Inflammatory Cells 261 Borel, Y.; Fritsché, R.; Borel, H.; Dahlgren, U.; Dahlman-Höglund, A.; Telemo, E.; Hanson, LA. Food Allergens Transformed into Tolerogens 264

Vieluf, D.; Przybilla, B.; Schwerbrock, U.; Ring, J. Oral Provocation Test in the Diagnosis of Anaphylactoid Reactions to 'Mild' Analgesic Preparations 268

Touvay, C; Vilain, B.; Carre, C; Mencia-Huerta, J.M.; Braquet, P. Effect of Limonene and Sobrerol on Monocrotaline-Induced Lung Alterations and Pulmonary Hypertension 272 Allergens and Immunotherapy

Hetzel, C; Hoyne, G.F.; Lamb, J.R. Peptide-Mediatedlmmunoregulation 275

Suko, M.; Mori, A.; Ito, K.; Okudaira, H. Oral Immunotherapy May Induce T Cell Anergy 278

Durham, S.R.; Kay, A.B.; Hamid, Q. Changes in Allergic Inflammation Associated with

Successful Immunotherapy 282

Løwenstein, H.; Sparholt, S.H.; Klysner, S.S.; Ipsen, H; Larsen, J.N. The Significance of Iosallergenic Variations in Present and Future Specific Immunotherapy 285

Vrtala, S.; Grote, M.; Ferreira, F.; Susani, M.; Stocker, B.; Kraft, D.; Valenta, R. Humoral Immune Responses to Recombinant Tree Pollen Allergens (Bet v I and Bet v II) in Mice:

Construction of a Live Oral Allergy Vaccine 290

Arruda, L.K.; Vailes, L.D.; Benjamin, D.C.; Chapman, M.D. Molecular Cloning of German Cockroach (Blattella germanica) Allergens 295

Homer, W.E.; Reese, G; Lehrer, S.B. Identification of the Allergen Psi c 2 from the Basidiomycete Psilocybe cubensis as a Fungal Cyclophilin 298

Platts-Mills, T.A.E.; Sporik, R.; Ingram, J.M.; Honsinger, R. Dog and Cat Allergens and Asthma among School Children in Los Alamos, New Mexico, USA: Altitude 7,200 feet 301

Management and Drug Therapy

Carballido, J.M.; Aversa, G; Schols, D.; Inhibition of Human IgE Synthesis in vitro and in SCID-hu Mice by an Interleukin-4 304

Punnonen, J.; de Vries, J.E. Receptor Antagonist

6 
Contents

Shields, R.L; Whether, W.R.; Zioncheck, K.; $\quad$ Inhibition of Allergic Reactions with Antibodies to IgE $\quad 308$

O’Connell, L.; Fendly, B.; Presta, L.G.; Thomas, D.; Saban, R.; Jardieu, P.

Jacquemin, M.G.; Saint-Remy, J.-M.R. Epitope-Specifíc Down-Regulation of Anti-Allergen Antibodies following Injection of Allergen-Antibody Complexes in Hypersensitive Patients 313 Bitoh, S.; Wakefield, R; Lang, G.M.; Sehon, A.H. Inhibition of the Effector Phase of IgEMediated Allergies by Tolerogenic Conjugates of Allergens and Monomethoxypolyethylene Glycol 316

Drazen, J.M.; Israel, E. Treatment of Chronic Stable Asthma with Drugs Active on the 5Lipoxygenase Pathway 319

Egan, R.W.; Athwahl, D.; Chou, C.-C; Emtage, S.; Jehn, C.-H.; Kung, T.T.; Mauser, P.J.; Murgolo, N.J.; Bodmer, M.W. Inhibition of Pulmonary Eosinophilia and Hyperreactivity by Antibodies to Interleukin-5 321

Wershil, B.K.; Furuta, G.T.; Lavigne, J.A.; Choudhury, A.R.; Wang, Z.S.; Galli, S.J.

Dexamethasone and Cyclosporin A Suppress Mast Cell-Leukocyte Cytokine Cascades by Multiple Mechanisms 323

Beasley, R.; Pearce, N.; Crane, J.; Burgess, C. Withdrawal of Fenoterol and the End of the New Zealand Asthma Mortality Epidemic 325

Effectors and Pathogenesis of Allergic Diseases

Nettleton, M.Y.; Kochan, J.P. Role of Glycosylation Sites in the IgE Fc Molecule 328

Saito, H.; Miura, K.; Takahashi, G; Ebisawa, M.; Matsumoto, K.; Shichijo, M.; Onda, T.; Iikura, Y.; Yanagihara, Y.; Ra, C. Development of Tryptase-Positive KU812 Cells Cultured in the Presence of Steel Factor 330

Brownell, E.; Fiorentino, L.; Jolly, G; Wolfe, K.; Kincaid, S.; Seperack, P.; Visco, D. Immunolocalization of Stromelysin-Related Protein in Murine Mast Cell Granules 333 Columbo, M.; Bochner, B.S.; Marone, G. Human Mast Cells Adhere to Extracellular Matrix Proteins through Their Selective Expression of $\beta 1$ Integrins 336

Simon, H.-U.; Yousefi, S.; Blaser, K. Tyrosine Phosphorylation Regulates Activation and Inhibition of Apoptosis in Human Eosinophils and Neutrophils 338

Shute, J.K.; Lindley, I.; Peichl, P.; Holgate, ST.; Church, M.K.; Djukanovic, R. Mucosal IgA Is an Important Moderator of Eosinophil Responses to Tissue-Derived Chemoattractants 340 Lim, K.G.; Wan, H.-C; Resnick, M.;

Wong, D.T.W.; Cruikshank, W.W.; Kornfeld, H.;

Center, D.M.; Weller, P.F. Human Eosinophils Release the Lymphocyte and Eosinophil Active Cytokines, RANTES and Lymphocyte Chemoattractant Factor 342

Wan, H.-C; Lazarovits, A.I.; Cruikshank, W.W.; Kornfeld, H.; Center, D.M.; Weller, P.F. Expression of $\alpha 4 \beta 7$ Integrin on Eosinophils and Modulation of $\alpha 4$-Integrin-Mediated Eosinophil Adhesion via CD4 343

Zeck-Kapp, G; Kapp, A. Subcelluar Mechanisms of Eosinophil Degranulation: The Role of RANTES, Interleukin-5 and Tumor Necrosis Factor- $\alpha 345$

Ebisawa, M.; Shichijo, M.; Endo, H.; Shimoda, H.; Miura, K.; Saito, H.; Iikura, Y. Phenotypic Analysis of Hypodense Eosinophils Derived from Ascites of a Patient with Ascariasis 346 Minnicozzi, M.; Gleich, G.J.; Durán, W.N.; Egan, R.W. Increased Microvascular Permeability Induced by Eosinophil Proteins 348 
Thomas, P.; Mehlbrech, J.; Eberlein-Koenig, B.; Przybilla, B. Molds Modulate the Release of Histamine and Sulfidoleukotrienes from Human Basophils 349

Rumpel, E.; Pilatus, U.; Mayer, A.; Pecht, I. Na+ and Ca2+ Gradients across the Membrane Modulate the Secretory Response of Mast Cells 351

Li, Y.; Richards, D.; Noble, A.; Kemeny, D.M. Cytokine Production by Highly Purified Human CD8+T Cells 354

$\beta$

Onda, T.; Messier, H.; Bissonette, R.;

Antigen-Specific Immunoregulatory Activity of a T

Cell Receptor $\alpha$ Chain Generated 356

Echeverri, F.; Baier, G.; Fotedar, A.; Green, D.R. py Expression PCR

Santamaria, L.F.; Perez Soler, M.T.; Hauser, C; Blaser, K. Allergen Specificity and Endothelial Transmigration of T Cells in Allergic Contact Dermatitis and Atopic Dermatitis Are Associated with the Cutaneous Lymphocyte Antigen 359

Askenase, P.W.; Ptak, W.; Szczepanik, M. $\gamma \delta$ T Cells in Normal Murine Spleen Assist Immunized $\alpha \beta$ T Cells in the Adoptive Cell Transfer of Contact Sensitivity: Effect of Bordetella pertussis. Cyclophosphamide, and Antisuppressor T Cell Monoclonal Antibodies 363

Matsuda, H.; Ptak, W.; Askenase, P.W. Role of Mast Cells versus Basophils in IgE-Dependent Local Ear Skin Release of the Serotonin Required to Initiate Contact Sensitivity in Mice 364 Paliwal, V.; Ptak, W.; Askenase, P.W. Regulation of Allergic Contact Sensitivity in Mice: Soluble $\alpha \beta$ T Cell Receptors,

Derived via cDNA Transfection and Enzymatic Cleavage from the Surface of

T Cells, Protect Contact Sensitivity Effector T Cells from Active T Cell Suppression 365

Mori, A.; Inoue, S.; Mikami, T:, Kaminuma, 0.; Ohmura, T.; Nishizaki, Y.; Asakura, Y.; Suko, M.; Ito, K.; Okudaira, H. Analysis of Human Interleukin-5 Gene Transcription by T Cell Clones and Hybridomas 366

Worm, M.; Geha, R.S. Activation of Tumor Necrosis Factor- $\alpha$ and Lymphotoxin- $\alpha$ via AntiCD40 in Human B Cells 368

Ballow, M.; Weiping, W. Retinoic-Acid-Induced Enhancing Effects of Immunoglobulin Synthesis by Human B Cells 370

Walls, A.F.; He, S.; Teran, L.M.; Buckley, M.G.; Jung, K.-S.; Holgate, S.T.; Shute, J.K.; Cairns, J.A. Granulocyte Recruitment by Human Mast Cell Tryptase 372

Teran, L.M.; Carroll, M.; Frew, A.J.; Montefort, S.; Lau, L.C.K.; Davies, D.E.; Lindley, I.; Howarth, P.H.; Church, M.K.; Holgate, S.T. Neutrophil Influx and Interleukin-8 Release after Segmental Allergen or Saline Challenge in Asthmatics 374

Frew, A.J.; Teran, L.M.; Madden, J.; Trefilieff, A.; St. Pierre, J.; Semper, A.; Carroll, M.P.; Holgate, S.T. Cellular Changes 24 Hours after Endobronchial Allergen Challenge in Asthma 376 Koshino, T.; Arai, Y.; Miyamoto, Y.; Sano, Y.; Takaishi, T.; Hirai, K.; Ito, K.; Morita, Y. Mast Cell and Basophil Number in the Airway Correlate with the Bronchial Responsiveness of Asthmatics 378

Heymann, P.W.; Rakes, G.P.; Hogan, A.D.; Ingram, J.M.; Hoover, G.E.; Platts-Mills, T.A.E. Assessment of Eosinophils, Viruses and IgE Antibody in Wheezing Infants and Children 380 Hilger, R.A.; Köller, M.; Fränken, J.; Rihoux, J.P.; König, W. Interactions of Cytokines and Lipid Mediators in Acute and Chronic Inflammation 383

Hermann, K.; Donhauser, S.; Ring, J. Angiotensin in Human Leukocytes of Patients with Insect Venom Anaphylaxis and Healthy Volunteers 385 
Tonnel, A.B.; Janin, A.; Copin, M.C.; Gosset, P.; Gosselin, B.; Wallaert, B. Airway-Like Inflammation of Minor Salivary Glands in Bronchial Asthma 387

Djukanovic, R.; Howarth, P.; Vrugt, B.; Wilson, S.; Semper, A.; Bradding, P.; Aalbers, R.;

Holgate, S. Determinants of Asthma Severity 389

Howarth, P.H.; Bradding, P.; Feather, I.; Wilson, S.; Church, M.K.; Holgate, S.T. Mucosal

Cytokine Expression in Allergic Rhinitis 390

Arnold, R.; Werchau, H.; König, W. Expression of Adhesion Molecules (ICAM-1, LFA-3) on

Human Epithelial Cells (A549) after Respiratory Syncytial Virus Infection 392

Foreman, K.E.; Glovsky, M.M.; Warner, R.L.; Horvath, S.J.; Ward, P.A. Does Complement

Activation Control 'Tissue Trafficking' by C3a and C5a Anaphylotoxin Generation? 394

Sanderson, I.R.; Walker, W.A. $\quad$ Establishment of a Human Fetal Small Intestinal Epithelial

Cell Line 396

8 Contents

Clinical Features, Management and Pharmacology of Allergic Diseases

Lanes, S.; Birmann, B.; Walker, A.; Sheffer, A.L.; Bosiello, R.; Dreyer, N. The Characterization and Evaluation of Current Asthma Management 398

Fabbri, L.M.; Mapp, C.E.; Balboni, A.; Baricordi, R. HLA Class II Molecules and Asthma Induced by Toluene Diisocyanate 400

Matsuda, S.; Onda, T.; Iikura, Y. Bronchial Responses of Asthmatic Patients in an AtmosphereChanging Chamber. 2. Effects of Exercise at High Altitude 402

Merget, R.; Caspari, C; Kulzer, R.; Breitstadt, R.; Rueckmann, A.; Schultze-Werninghaus, G.

The Sequence of Symptoms, Sensitization and Bronchial Hyperresponsiveness in Early

Occupational Asthma due to Platinum Salts 406

Tanaka, R.D.; Clark, J.M.; Warne, R.L.; Abraham, W.M.; Moore, W.R. Mast Cell Tryptase: A

New Target for Therapeutic Intervention in Asthma 408

Arruda, L.K.; Muir, A.; Vailes, L.D.; Selden, R.F.; Platts-Mills, T.A.E.; Chapman, M.D.

Antibody Responses to Aspergillus fumigatus Allergens in Patients with Cystic Fibrosis 410

Shields, R.L.; Werther, W.R.; Zioncheck, K.; O'Connell, L.; Klassen, T.; Fendly, B.; Presta, L.G.; Jardieu, P.M. Anti-IgE Monoclonal Antibodies that Inhibit Allergen-Specific Histamine

Release 412

Farrar, J.R.; Rainey, D.K.; Norris, A.A. Pharmacologic Modulation of Thl and Th2 Cell Subsets by Nedocromil Sodium 414

Paulmichl, M.; Norris, A.A.; Rainey, D.K. Role of Chloride Channel Modulation in the

Mechanism of Action of Nedocromil Sodium 416

Devalia, J.L.; Davies, R.J.; Befus, A.D.; Bissonnette, E.Y.; Levi-Schaffer, F.; Rainey, D.K.;

Norris, A.A. Inhibitory Effects of Nedocromil Sodium on Cytokine Production from Mast and Epithelial Cells 417

Hey, J.A.; del Prado, M.; Egan, R.W.; Sherwood, J.; Kreutner, W. Loratadine Produces

Antihistamine Activity without Adverse CNS, ECG or Cardiovascular Effects in Guinea Pigs.

Comparative Studies with Terfenadine and Sedating Antihistamines 418

Yumibe, N.; Huie, K.; Chen, K.-J.; Clement, R.P.; Cayen, M.N. Identification of Human Liver

Cytochrome P450s Involved in the Microsomal Metabolism of the Antihistaminic Drug

Loratadine 420

Rihoux, J.P.; Fadel, R. Bradykinin-Induced Immediate Skin Reactions and 5/8-Blockade 421 
Howarth, P.H.; Harrison, K.; Lau, L. The Influence of 5-Lipoxygenase Inhibition in Allergic Rhinitis 423

Karlsson, J.-A.; Souness, J.; Webber, S.; Pollock, K.; Raeburn, D. Anti-Inflammatory Effects of the Novel Phosphodiesterase IV Inhibitor RP 73401425

Adachi, M.; Konno, S. Roxithromycin: Its Effects on Concanavalin-A Induced Spleen Cell

Proliferation and Interleukin Production in Mice 427

Davies, R.J.; Wang, J.H.; Trigg, C.J.; Devalia, J.L. Expression of Granulocyte/Macrophage-

Colony-Stimulating Factor, Interleukin-8 and RANTES in the Bronchial Epithelium of Mild

Asthmatics Is Down-Regulated by Inhaled Beclomethasone Dipropionate 428

Zwadlo-Klarwasser, G.; Hamann, W.; Flöter, A.; Schmutzler, W. New Anti-Inflammatory

Proteins Secreted by Human Glucocorticoid-Treated Macrophages 430

Tibes, U.; Vondran, A.; Rodewald, E.; Friebe, W.-G; Schäfer, W.; Scheuer, W. Inhibition of Allergic and Non-Allergic Inflammation by Phospholipase A2 Inhibitors 432

Middleton, E., Jr.; Anne, S.; Quercetin Inhibits Lipopolysaccharide-Induced Expression of

Endothelial Cell Intracellular Adhesion Molecule-1 435

McAloon, M.H.; ChandraSekar, A.; Lin, Y.-L; Hwang, G.C.; Sharpe, R.J. Buspirone Inhibits

Contact Hypersensitivity in the Mouse 437

Johnson, M. Anti-Inflammatory Properties of Fluticasone Propionate

439

ß

9

Johnson, $\mathrm{M}$.

Effect of Fluticasone Propionate on Acute and Chronic Inflammation

441

Panzani, R.C.; Falagiani, P.; Riva, G; Delord, Y.; Mercier, P.

Screening for Atopy in a Coffee-Processing Factory

443

Sanz, M.L.; de las Marinas, M.D.; Ferrer, M; Oehling, A.

Specific Immunotherapy Induces Changes in Spontaneous IgE Synthesis 445

Crane, J.; Beasley, R.; Stewart, B.; Shaw, R.; Pearce, N.; Burgess, C.

The International Asthma Video Questionnaire for Measuring Asthma Prevalence in 450

Different Populations

465

Allergens

Oliver, J.; Birmingham, K.; Crewes, A.; Weeks, J.; Carswell, F. Allergen Levels in Airborne and Surface Dust 452

Levy, D.A.; Kekwick, R.G.O.; Bhambri, S.; Autegarden, J.-E.; Leynadier, F. Latex, an Intriguing Allergen 454

Arruda, L.K.; Fernandez-Caldas, E.; Naspitz, C.K.; Montealegre, F.; Vailes, L.D.; Chapman, M.D. Identification of Blomia tropicalis Allergen Bio t 5 by cDNA Cloning 456 
Breitenbach, M.; Achatz, G.; Oberkofler, H.; Simon, B.; Unger, A.; Lechenauer, E.; Kandler, D.; Ebner, C; Kraft, D. Molecular Characterization of Allergens of Cladosporium herbarum and Alternaria alternans 458

Crameri, R.; Blaser, K. Cloning Allergens from Aspergillus fumigatus: The Filamentous Phage Approach 460

Helm, R.; Crespo, J.F.; Cockrell, G; Stanley, J.S.; Brenner, R.J.; Burks, W.; Bannon, GA.

Isolation and Characterization of Clones Encoding Cockroach Allergens 462

Jäger, L.; Müller, W.D.; Fahlbusch, B. Immunological Analyses of Phi p V 464

Schuurman, J.; Lourens, T.E.; Perdok, G.J.; Parren, P.W.H.I.; Aalberse, R.C.

Mouse/Human Chimeric IgE Antibodies Directed to the House Dust Mite Allergen Derp2

Author Index Vol. 107, No. 1-3, 1995

Subject Index Vol. 107, No. 1-3, 1995

467470

\section{S. Karger}

Medical and Scientific Publishers Basel · Freiburg · Paris · London New York · New Delhi ·

Bangkok Singapore $\cdot$ Tokyo $\cdot$ Sydney

Drug Dosage

The authors and the publisher have exerted every effort to ensure that drug selection and dosage set forth in this text are in accord with current recommendations and practice at the time of publication. However, in view of ongoing research, changes in government regulations, and the constant flow of information relating to drug therapy and drug reactions, the reader is urged to check the package insert for each drug for any change in indications and dosage and for added warnings and precautions. This is particularly important when the recommended agent is a new and/or infrequently employed drug.

All rights reserved.

No part of this publication may be translated into other languages, reproduced or utilized in any form or by any means, electronic or mechanical, including photocopying, recording, microcopying, or by any information storage and retrieval system, without permission in writing from the publisher or, in the case of photocopying, direct payment of a specified fee to the Copyright Clearance Center (see 'Information for Readers and Subscribers').

(C) Copyright 1995 by S. Karger AG, P.O. Box, CH-4009 Basel (Switzerland) Printed in Switzerland on acid-free paper by Reinhardt Druck, Basel ISBN 3-8055-6206-3

10

Contents 